I. CONTACT AND MULTILINGUALISM AS AN OUTCOME OF SPEAKERS IN CONTACT 
Journal of language contact - THEMA 3 (2010) www. jlc-journal.org 


\title{
THE MANDE AND ATLANTIC GROUPS OF NIGER-CONGO: PROLONGED CONTACT WITH ASYMMETRICAL CONSEQUENCES
}

\author{
G. Tucker Childs* \\ Portland State University
}

\section{Introduction}

Africa features a number of long-standing contact situations between groups speaking unrelated languages. In a broad band across the sub-Saharan region from east to west many such situations can be identified, including the Atlantic-Mande contact region of western West Africa. The interaction between speakers of Atlantic languages and speakers of Mande languages has pointed predominantly in only one direction as to (linguistic) influence, namely, from Mande to Atlantic. ${ }^{1}$ Why this is so can be explained with reference to historical and socio-cultural factors. Although there are exceptions to this directionality, the exceptions actually reinforce these explanations. This paper explores the structural consequences of the contact between Mande and Atlantic and the reasons for this mono-directionality, concentrating primarily on the affected group, speakers of Atlantic languages. In terms of Mande-Atlantic interaction, the most common practice has been for speakers of Atlantic languages to adopt the culture and language of speakers of Mande languages.

The main purpose of this paper is to examine a subset of the variety of language contact situations between speakers of Mande languages and speakers of Atlantic languages (hereafter "Mande" and "Atlantic"). Simultaneously it underscores the need for deeper research, especially in the case of Atlantic's undocumented languages (Childs 2008),

\footnotetext{
* I am grateful to the following funding agencies: Fulbright Commission, Endangered Language Foundation, Bremer Stiftung für Kultur- und Sozialanthropologie, Hans Rausing Endangered Languages Program, SOAS, University of London, and the National Science Foundation; and the host country institutions Fourah Bay College (Sierra Leone) and the University of Conakry (Guinea), and our hosts in West Africa, the Mani people of the Samu and Bom and Kim speakers in the Kwamebai and Bum Chiefdoms.

${ }^{1}$ Valentin Vydrine (2003 p.c.) has warned that Mande is not a coherent entity and should not be treated as such. The same warning comes from historians such as Adam Jones (2008 p.c.). This statement is just as true for the even more fractured Atlantic Group (see discussion in 2.1.1 below). It is also the case that Atlantic has recently been decomposed into two separate groups, North Atlantic and South Atlantic, and an isolate, Bijogo (Blench 2006). I accept this analysis and refer to the branches by those names. Nonetheless, I adopt the terms "Mande" and "Atlantic" for heuristic purposes, as in Childs (2004a).
} 
investigating the socio-historical conditions in addition to the linguistic details. This need is particularly urgent in the case of the dying languages identified below in section 2.2.7.

Any survey of the literature on language contact between the two groups reveals the absence of such information against the preponderance of linguistic analysis. At times linguists seem preoccupied with the unusual or exotic results of language contact to the detriment of understanding the context and process by which such outcomes were achieved. The latter focus is much more likely to be found as part of the language documentation initiative (Himmelmann 2006; Woodbury 2003). Shallowness is a criticism of many contact studies. For some investigators, the existence of a shared feature across a genetic boundary is sufficient proof of influence, without any evidence of the interactional details, even when the classification itself is suspect. For others the analysis may be limited to borrowings, typically at the lexical level, with little exploration beyond those limited examples.

Probably because of the pioneering and generally accepted ("right" according to Newman 1995) classification system proposed for Africa by Joseph Greenberg (e.g. Greenberg 1963), the tradition in genetically classifying African languages has been one of lumping (grouping languages into a small number of phyla) rather than splitting, as laid out in Blench (1999) and Dimmendaal (2008). Scholars have accepted Greenberg's analysis of all African languages into just five phyla and most of his subdivisions, although there have been many criticisms (e.g. Dimmendaal 2001). ${ }^{2}$ Greenberg's model may have had a deleterious effect on further research, however, in suggesting that one could bypass the close analysis needed to establish genetic relationships (e.g. Dalby 1970; Dixon 1997). Language classification is, of course, a preliminary to contact study.

The contact scene is wildly under-researched (Heine 1997) and perhaps misanalyzed, particularly as one moves back in time, for the many reasons given in Childs (2003b). These include, at least: Africa's daunting field conditions, prejudice, ignorance, and even racism (Doneux 2003), the multiple research traditions in Europe arising from nationalistic and colonial rivalries, the lack of interest and resources on the part of Africans themselves, and the theoretical preoccupation of North Americans. Certainly the lumping tendency would be one cause for misanalysis, especially in its implications for language classification. Other weaknesses are more general, for example, how often "divergence processes [are seen as] the paradigm scenario of language history" (Güldemann 2008:184).

One tantalizing question that has been raised a number of times asks whether Africa as a whole constitutes a linguistic area. This would of course imply a great deal of contact over a widespread area for an extended period of time. That such a question has been raised a number of times (Greenberg 1959; Heine 2003) points again, ironically, to the lumping tradition. More crucially, however, it suggests that contact might be just as important if not more important than genetic inheritance for understanding the structures and relatedness of African languages. The relatively recent expansion of Niger-Congo and especially Bantu (Oliver 1966; Herbert and Huffman 1993) have led to the phylum's overweening influence on languages from other phyla with which it has been in contact (Childs 2009). The Bantu Expansion is not dissimilar to what is below called the "Mande Expansion", albeit on a much grander scale. Another major force at work has been the rise of the Sudanic empires and the spread of Islam. The types of contact that yield the most diverse varieties often involve significant and obvious disparities in power and resources, such as those listed below, not all of which are strictly orthogonal to each other.

(1) Relevant types of contact

- Trade beyond the immediate area, e.g. trans-Saharan, Indian Ocean

- Spread of cultural practices such as rituals and secret societies, e.g. Poro

\footnotetext{
${ }^{2}$ See more criticisms in Dixon (1997), Aikhenvald and Dixon (2001). Güldemann writes that Greenberg's lumping has "deprived African linguistics of some of its potentially more interesting fields of areal-linguistic research" (Güldemann 2008:184).
} 
- Technological innovations, e.g. the spread of agriculture, iron-working

- African, especially Sudanic, empire building

- European colonization and the slave trade

- Spread of new religions, especially Islam

- Urbanization, globalization and environmental degradation (loss of biodiversity)

All of these factors are relevant to the interactions between Atlantic and Mande. Section 1 locates Mande-Atlantic interaction within the African context and language contact studies in general. I then say something about the socio-historical patterns in Mande-Atlantic interactions (section 2.1) and turn to the micro- and macro-linguistic patterns in MandeAtlantic interactions (sections 2.2 through 2.2.8). In the conclusion, section 3, I indicate some directions for further research, including simple documentation, but also sociolinguistic and interdisciplinary studies.

\section{Literature review}

Little literature exists on the overall interactions between speakers of Mande and Atlantic languages and little more generally on the history of the area (Adam Jones 2008 p.c.). On the linguistic side, most of what can be found analyzes the interface between two languages, concentrating on borrowings into the target language, i.e. the one that is (linguistically) changed by the contact (e.g. Turay 1971; Ducos 1979). One might also remark that these are favorite thesis topics at West African universities, e.g. the University of Conakry, and Fourah Bay College, Sierra Leone, as Blench (2006) notes is true for Africa in general.

Just as there is little literature at the macro-level of language contact between Mande and Atlantic, no overarching review of contact phenomena in Africa exists, nor, in fact, may such a review be possible (Nurse 2008 p.c.), except in a very general way. ${ }^{3}$ A great number of publications, however, are of direct relevance to issues in language contact in Africa. Relevant topics within the African context include: language classification, historical and comparative linguistics, the sociology of language (multilingualism, language maintenance and language shift), books on language planning and language policy, and especially work on language endangerment and language death.

Several recent books discuss language contact as one of their major themes and are necessary reading for anyone considering the topic. Blench (2007) synthesizes findings from several distinct but related fields (including archaeology, comparative ethnology and DNA testing) to reconstruct the history of the continent. It is more his methodology than his findings that are of direct relevance to the Mande-Atlantic interface. Heine and Nurse (2008) contains much material relevant to issues in language contact, especially when used in concert with Haspelmath et al. (2005). Of the contributions to Heine and Nurse (2008), the one that is most relevant to this paper is one that considers the Sudan as a linguistic area (Güldemann 2008), a long-standing conundrum, seen variously as Sudansprachen (Westermann 1911), the languages of the "Fragmentation Belt" (Dalby 1970), or in this volume, the "Sudanic" phonological zone (Clements and Rialland 2008). As with others (Dalby 1966, 1970; Mukarovsky 1976-77), Güldemann finds the upper levels of genetic classification ultimately unsatisfying (an "anti-lumping approach" rather than a splitting one) and suggests that Greenberg's higher genetic groupings may be geographical. Güldemann's "linguistic area" (the term is used more loosely than elsewhere) in the Central Sudan is an "innovation area" that radiates features "primarily [as] the result of geographical factors which have been relevant for a sufficiently long time period" (Güldemann 2008:180). The features he identifies are given in (2).

\footnotetext{
${ }^{3}$ Such a volume has been promised (Güldemann in preparation).
} 
(2) Features defining the Macro-Sudan belt (Güldemann 2008)

1. Logophoricity

2. Labial velars

3. ATR vowel harmony

4. S-Aux-O-V-X

5. Word order $\mathrm{V}-\mathrm{O}-\mathrm{Neg}$

6. Labial flap consonants

Atlantic, he notes, is one of a number of "lineages" that "display an ambiguous behavior regarding linguistic commonalities with this area" (Güldemann 2008:152). With the exception of features 3 (height harmony is found in Atlantic) and 6, however, all features are found in the area under consideration. Another paper in this volume speaks of a "Sudanic linguistic area" (Clements and Rialland 2008: 81), although the authors find North Atlantic languages to be exceptional (p. 82). It is not clear why the South Atlantic languages and Bijogo are not also seen as exceptional, for they are indeed so in many of the same ways. ${ }^{4}$ The general point of this brief consideration of recent work on language contact in the MandeAtlantic area is that the area is not well understood and Atlantic in particular is said to be slightly anomalous. Further research, however, may prove this assessment to be inaccurate.

The question is, of course, whether Mande and Atlantic were in contact long enough for there to be enough transfer of features either one way or the other to make the families similar enough to each other to constitute a linguistic area? One problem is that "groups" of languages are not frequently in contact with each other. The interaction is usually on a 1:1 basis at geographical or sociological boundaries. A related problem is that the members of each group are not culturally homogeneous. Within Atlantic, for example, Temne, Wolof, and Fulfulde survived as widely spoken languages primarily because they were united at levels higher than the hamlet, the usual unit of organization for Atlantic groups. Within Mande, the speakers of the Mandeng languages, probably the result of the splintering of a group functioning centrally in the Mali Empire, were much more militaristic than, say, speakers of Eastern Mande languages. Other factors such as those suggested by the list in (1) are relevant: urbanization, employment patterns, technology, etc., all play a role in influencing contact outcomes.

The next section examines the interaction between these two Niger-Congo language groups, i.e. Atlantic and Mande. The study of their contact is informative for many reasons, not least because they are typologically quite different. Both groups are concentrated in the western part of West Africa and have been in contact for centuries. Their interaction ranges socially from partial to complete assimilation, and linguistically from a few borrowings to language shift and language death.

\section{Atlantic and Mande introduced}

Section 2.1 looks first at language classification so as to establish a basis for discussing contact between the two groups, then turns to a sketch of the history of their interactions and characterizes the social situation today. The second section (2.2) treats the linguistic consequences, first at the micro-level of individual features and languages, then at the macrolevel of language maintenance, language shift, and language death. Reference to the two maps in 2.2 may help the reader to understand the past and current configurations of peoples.

\subsection{Socio-historical background}

Before examining the socio-historical context within which these groups operate, I say something about each group's classification and constituency. Both groups split from the Niger-Congo trunk at a fairly early date. The date of the separation of Mande has been put at 2,000 BCE on the basis of Bimson (1978), a study using glottochronology (Dwyer 1989:50;

\footnotetext{
${ }^{4}$ Both Kisi and Temne (South Atlantic) as well as Bijogo (an isolate) form part of the database (along with five North Atlantic languages).
} 
Kastenholz 1991/92); this date is probably the same for the separation of at least North and South Atlantic.

\subsubsection{Classification}

Atlantic and Mande constitute at least two and possibly three or more distinct early branches off the Niger-Congo stock (Blench 2006:116-17), Mande being the more coherent of the two. ${ }^{5}$ The unity of Atlantic has long been questioned (Mukarovsky 1976-77; Bennett and Sterk 1977: 248; Wilson 1989). The received classification of Niger-Congo is given in Figure 1.

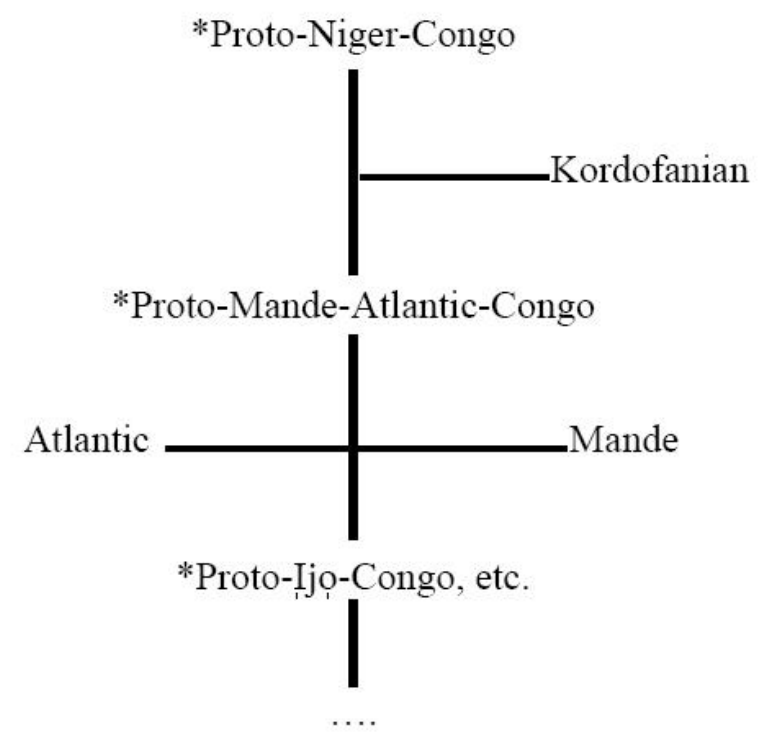

Figure 1: Niger-Congo (Williamson and Blench 2000)

The Atlantic Group consists of approximately fifty languages (43 in one count, 63 in another), many of them well known, e.g. Wolof and Fulfulde. The majority of them, however, are not widely spoken and are threatened by more widely spoken languages, both within and outside Atlantic, as is generally the case in Africa (Brenzinger et al. 1991). The language group is found in a broad swath along the Atlantic coast from Senegal to Liberia, roughly speaking, and consists of two disparate branches and an isolate.

Atlantic is not a unified group, at least from a linguistic perspective. The work of Segerer has shown that Bijogo has closer links outside Atlantic than within and thus stands as an isolate (e.g. Segerer 2000). My own work has shown that South Atlantic forms no genetic unity with North Atlantic, even on the geographic and typological criteria typically used to unify the group (Childs 2001; 2003c). These findings have recently been integrated into a single representation, as shown in Figure 2. I have included only the top part of the classification down to just below Bijogo. The figure shows North Atlantic and South Atlantic as independent branches separating from the Niger-Congo stock at approximately the same time, with Bijogo separating much later.

\footnotetext{
${ }^{5}$ Mande has also been analyzed as not belonging to Niger-Congo (Dimmendaal 2008:842). 


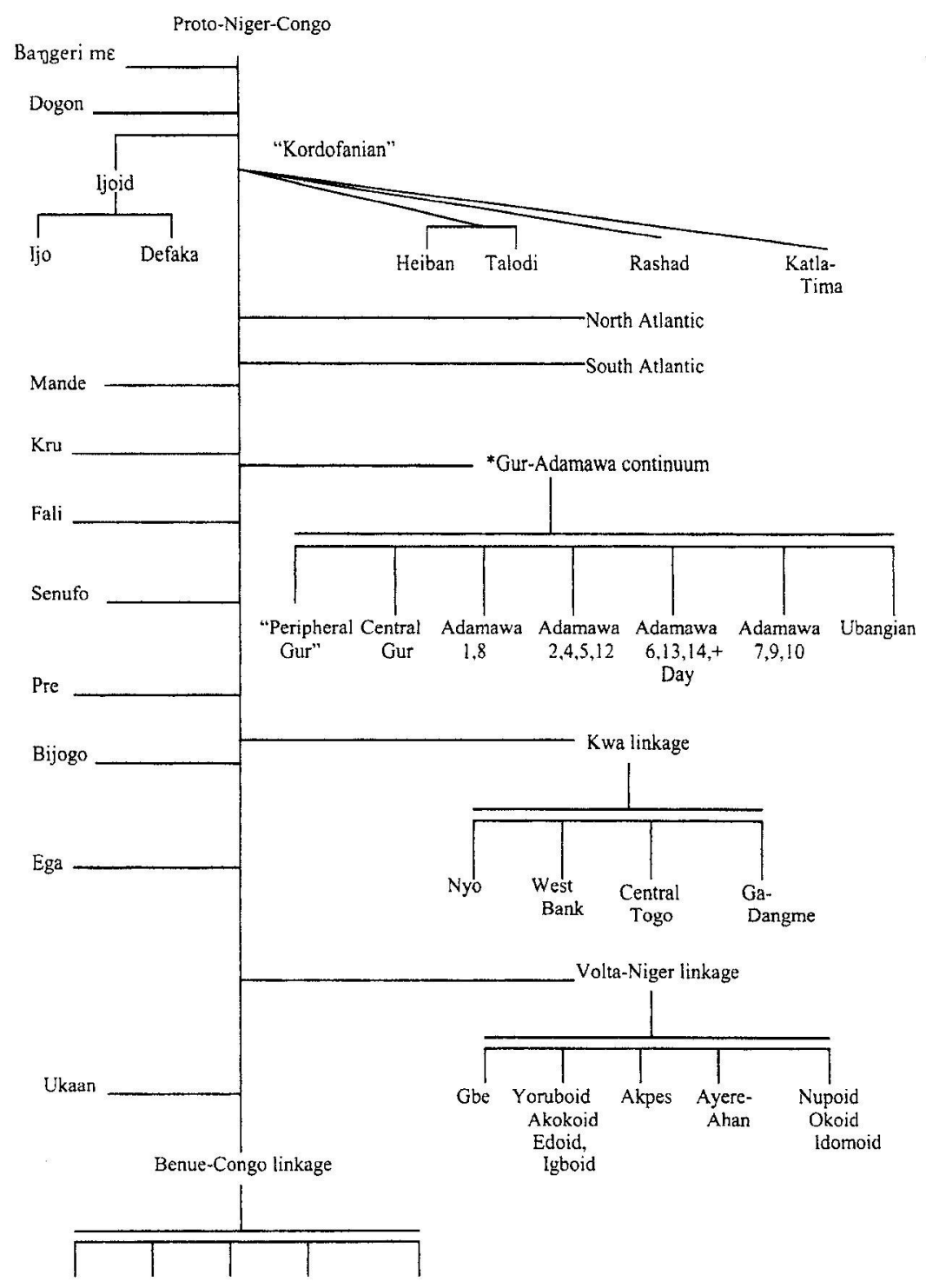

Source: Blench (2004b)

Figure 2: Niger-Congo (Blench 2006:118)

The Mande languages are spoken in a large area covering much of the western Sudan. To the west, Mande languages are spoken right up to the Atlantic Ocean, where they surround pockets of Atlantic speakers. With regard to the group, however, the question has often arisen, "Does Mande really belong in Niger-Kordofanian, and if so, why does it look so different from other languages in the phylum?" (Newman 2000:271; see note 5). Although this question cannot be answered here, that it has been posed indicates the group's distinctiveness. Mande has undergone no major changes since Greenberg's classification, and most scholars accept as Mande the languages included in the genetic tree proposed below. 


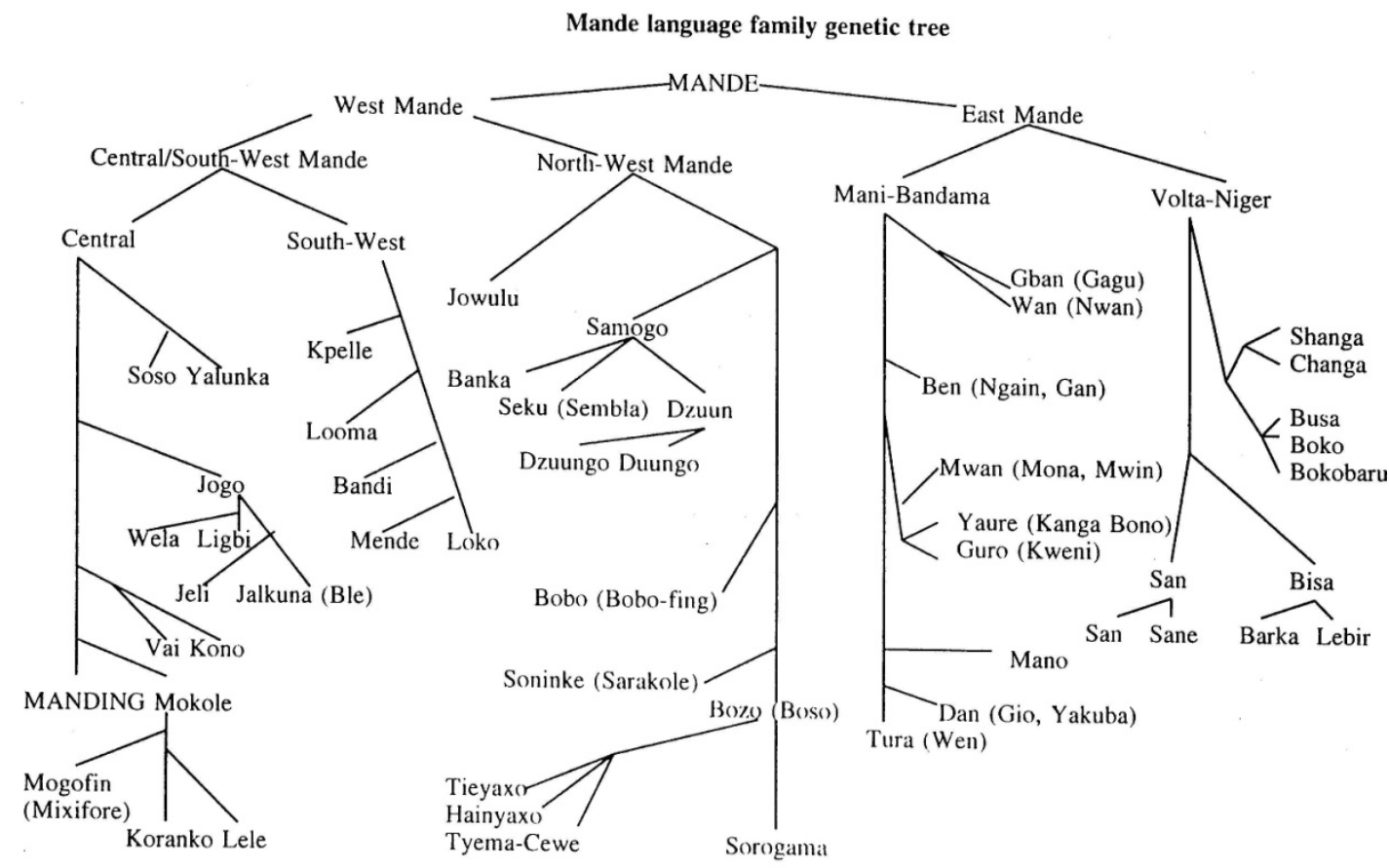

Figure 3: Mande language family genetic tree (Vydrine 1999)

The display above shows only some forty-five languages, but others reckon there are many more: seventy-one languages in Gordon (2005), and Vydrine (2005 and p.c.) also puts the total at seventy ( $c f$. Kastenholz 1991/92). In the same personal communication Vydrine could identify only a few dying languages; Kastenholz has identified more but still less than ten (Kastenholz p.c., referencing Kastenholz 1994; 1998; 2001).

This brief treatment suggests that, generally speaking, the languages belonging to Mande are rather better off in terms of vitality than their counterparts in Atlantic, where several languages have disappeared in historical times, others have only a few speakers, and a great many are seriously threatened.

\subsubsection{Historical background}

The Atlantic peoples were undoubtedly the first to occupy the area under discussion; at the least they arrived before the Mande (Niane 1989). Well before the spread of the Mande peoples, the South Atlantic peoples may have migrated from the Futa Jallon in the north, according to several oral histories (Schaeffner 1951; cf. Kup 1961:130). Thus, they were the original inhabitants of the area stretching at least from the Futa Jallon southwards. Blench is slightly more cautious:

\footnotetext{
Although no one is certain, several groups in the South Atlantic group claim a northern origin; just as uncertain as the Atlantic homeland is the homeland of the Mande themselves (Blench 2006:84).
}

The Mande peoples came to the area much later, probably from the interior of the Sudan, beginning in the first millennium. Historians have characterized this spread with the revealing appellation, the "Mande Expansion", in the face of which the Atlantic peoples gradually retreated towards the sea, the forest, and the highlands. In many cases they were eventually engulfed by speakers of Mande languages. Historically and socio-culturally the Atlantic and Mande peoples were originally quite distinct. Considerable convergence, however, has taken place over time as the groups interacted and commingled. 
There were basically two phases to what has been called the Mande Expansion, the first peaceful and gradual, the second more warlike and concentrated (Brooks 1993). ${ }^{6}$ In the first phase, Mande penetration of western Africa was characterized by a lengthy period of peaceful trade and settlement beginning in the early centuries of the Common Era (Niane 1989). The first phase comprised a steady influx of smiths and traders, the former obtaining power through their control of secret societies, the latter through their control of commerce and external contacts. The Mande generally did not assimilate to the Atlantic people among whom they settled and took wives, but maintained a separate identity. In the north, for example,

\begin{abstract}
Mandinka traditions concerning the Fati and Sane families, two Mande clans long involved in commerce, relate how members [settled along and south of the Gambia River] during the c.1100-c.1500 dry period with both groups reportedly settled peacefully among their [Atlantic] hosts, yet at the same time retaining their Mande linguistic, social, and cultural attributes (Brooks 1993:67).
\end{abstract}

The second phase is characterized below:

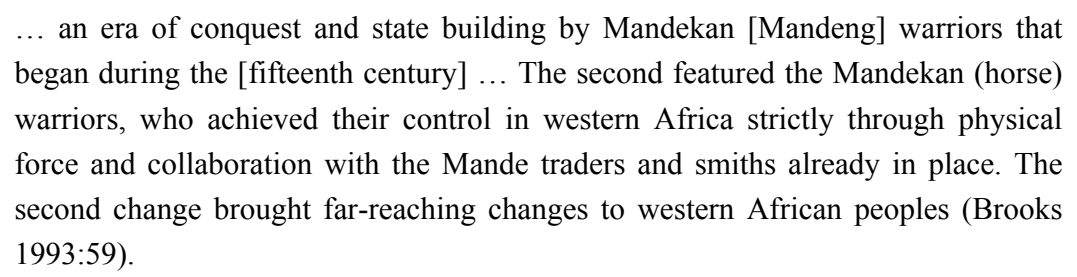

In the north more than in the south there are histories of major polities clashing, although there were also some of the same interactions characterizing the smaller groups (Delafosse 1924; Germaine 1984). The birth of the Gabou kingdom in present-day Senegal is dated to 1240 with the arrival of the warrior Sunjata. The story of one group of people that they overcame, the Bainouk, is fairly typical (Atlantic language 27 "nyun" on Maps 1 and 2 below). The Bainouk first opposed the invaders but with little success. Although they were considered maitres $d u$ sol, eventually their kingdom was destroyed along with all their traditions. By the nineteenth century they were completely assimilated to their conquerors (mandinguisé / 'Mandinguinized') (Niane 1989). ${ }^{7}$ Only the larger kingdoms such as the Wolof, who essentially adopted Mande ways, were able to resist. The smaller groups were all overcome, e.g. the Balanta ("balante", 16), Biafada ("Biafada", 17), Basari ("basari", 9), and Wamei ("wamei (konyagi)", 11).

Mande-speaking peoples spread westward from the area of present-day Mali and Haute Guinée in the south, forcing such groups as the Bullom (Atlantic languages 39-43) and Gola (38) towards the coast, much in the same way as the Kru (the southernmost languages on the maps) were forced into southern Ivory Coast by other Mande groups (Person 1966). The Kisi were split from their Bullom relatives, Sherbro, Bom, Kim and Mani, by an invasion of Mane warriors, and eventually established themselves in the uninhabited rain forest.

Those South Atlantic groups that have preserved their history, e.g. the Mani (41), recount stories of being pushed to the sea (Childs In press). The Kisi (37) fled from the Mane invaders (Rodney 1967) and are now completely surrounded by Mande groups. The Kisi have probably survived as a fairly viable group because of their isolation in the forests and more inhospitable regions (Paulme 1954; Childs 1995a) but have also engaged in warfare with the Bandi (Southwestern Mande) as recently as the 1940s. The scenario, then, is one of a large

\footnotetext{
${ }^{6}$ Much of this discussion comes from Childs (2002).

${ }^{7}$ Editor Friederike Lüpke notes that the situation is much more complex: "While speakers of Eastern varieties of Bainouk have Mandinka as the main contact language, the Gunyaamolo and Gubaher varieties have different Joola varieties as the main contact languages (Bühnen 1994; FL fieldwork)."
} 
number of indigenous forest tribes pushed westward by the movement of Mande-speaking peoples from the interior savannah (d'Azevedo 1959:50).

The conquest and subsequent acculturation and social stratification had linguistic implications. For example, matrilineality disappeared from both North and South Atlantic groups, surviving only among the Bijogo (29) on their isolated islands. A few traces remain among the Mani and Kim in naming practices and female paramount chiefs. The linguistic consequences were substantial: "With few exceptions the warriors spoke Mandekan languages that subsequently diffused among the conquered groups" (Brooks 1993:97; Murdock 1959:267ff).

In general the Atlantic speakers of the north had become organized beyond the hamlet (Mandinguinized?) before the Mandekan warriors appeared. They were the first to be infiltrated by the smiths and traders who only gradually moved their operations southwards. During the second phase in the north, the Mandekan warriors encountered the Jolof Kingdom, whose power they did not directly confront, and were deflected southward to below the Gambia, thus avoiding any imposition of their rule north of the Gambia. There was also significant resistance further south: the Fula were able to resist the onslaught because of their organization, their conversion to Islam, and militant proselytizing. This combination of factors prevented the Mandekan warriors from having as great an effect in the north as they did in the south.

I will next characterize the present-day geographic and social configurations of the two groups.

\subsubsection{Current geographical distribution}

Map 1 shows the entirety of the Atlantic territory today (excluding some far-flung Fulfulde speakers). The Atlantic languages appear in gold and the Mande languages in green. A brief examination shows that the majority of the Atlantic area consists of just two languages, Wolof (number "1" on Segerer's map) and Fulfulde (number "2", including "2bis"). It is these two languages that have acted similarly to the Mande languages in general, acting as "predatory languages" (Blench 2006), conducting glottophagie ['language eating'? TC] (Calvet 1974) on their less robust neighbors. ${ }^{8}$

\footnotetext{
${ }^{8}$ Childs (1995b) suggests that the reason for the robust survival and spread of Wolof and Fulfulde, as well as of Temne in Sierra Leone, is their speakers' adoption of Mande ways, especially their acceptance of hierarchical social structures, militarization and conversion to Islam.
} 


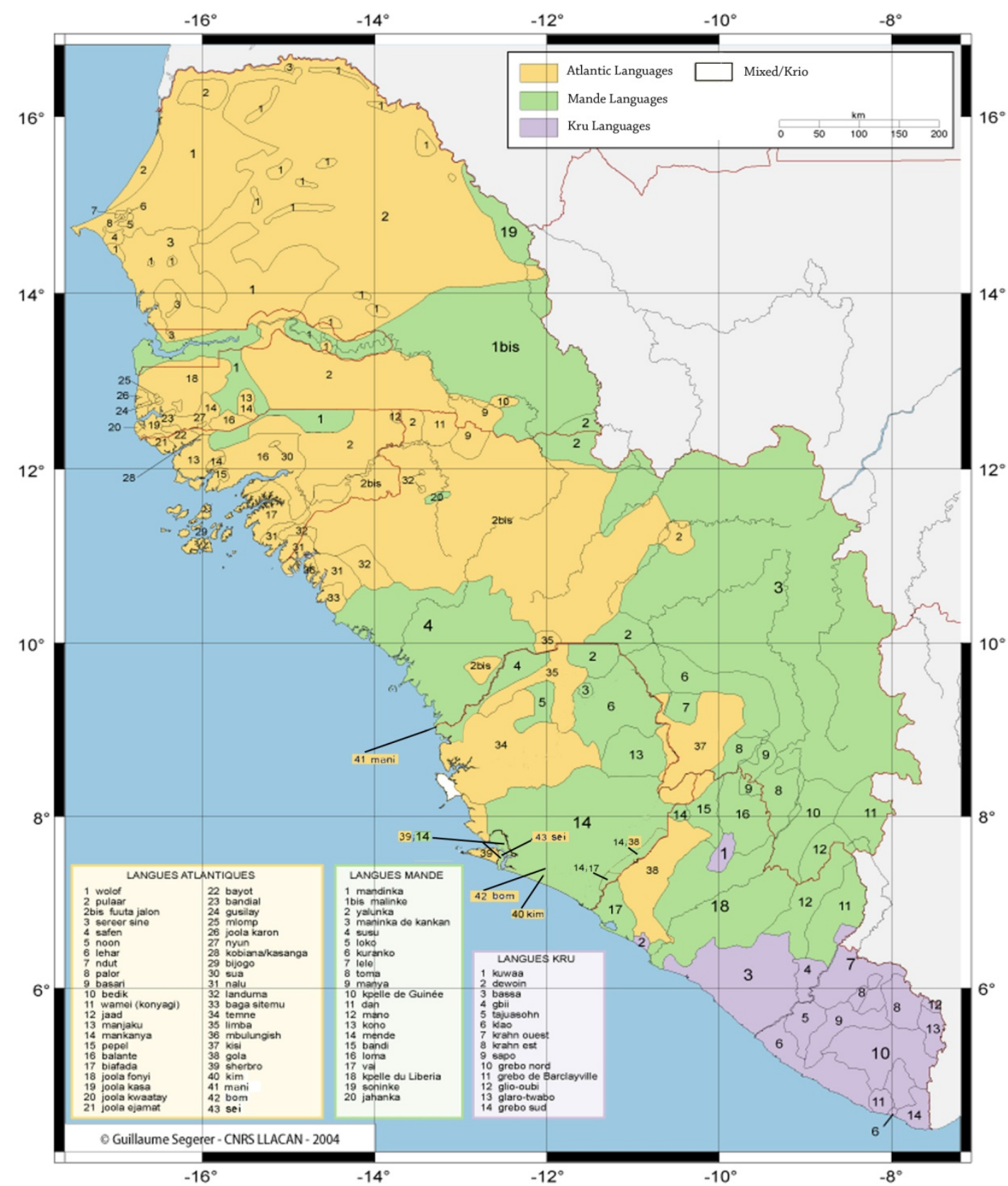

Map 1. The Atlantic languages (Segerer 2004 revised by the author 2008)

Map 2 shows the less widely spoken Atlantic languages more revealingly. In this display the more widely spoken languages being shifted to, Wolof (1), Fulfulde (2), and Temne (34), appear in red. The general picture that emerges is that of smaller groups being pushed towards the sea and in a few places being pushed into forests and highland areas.

Several features of this map show how peripheralized and reduced these smaller groups are. I will indicate only a few examples (the reader may want to refer back to Map 1 for others after this brief illustration). "Diola" represents a cluster of languages $(\mathrm{n}=6$ ? (Bassène 2007)), a number of which are threatened. "Cangin" is similarly a set of languages (Pichl 1966)) rather than a single language. Finally, the Gola area is much smaller than is represented on the map (Dalby 1962). 


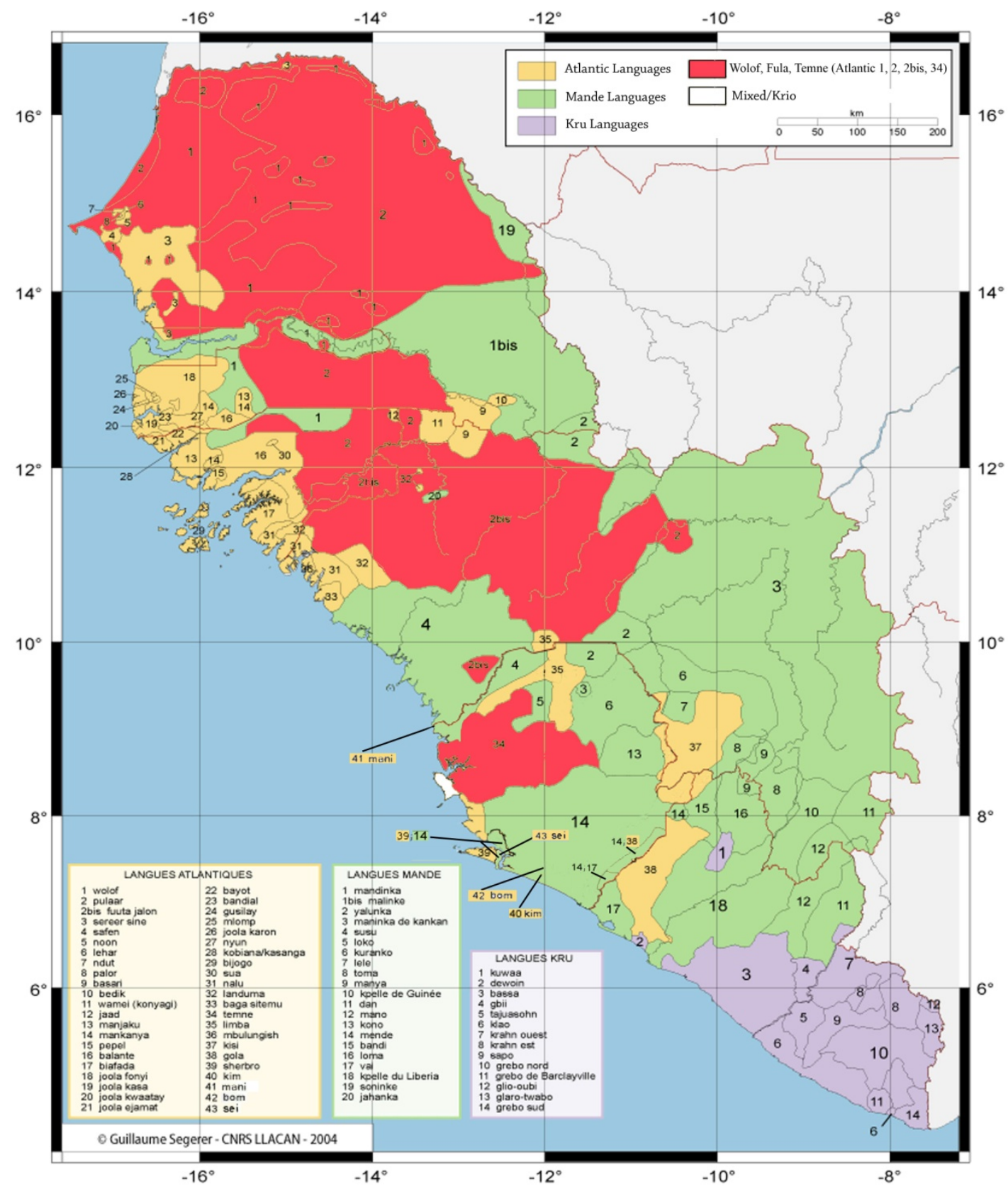

Map 2. The Atlantic languages (Segerer 2004 revised by author 2009)

\subsubsection{Social characterization}

What is revealed by a combination of history and synchronic geographical distribution is a general asymmetry in power and resources, with the newer arrivals, the Mande interlopers, having the upper hand. In this section I summarize the evidence for Mande superiority, which, as noted above, is manifested in their military might and in their skill at imposing their social structures on their hosts. There is an equivalent abundance of evidence for Atlantic inferiority. It is this disparity that has led to a situation ripe for one language to influence another in predictable ways.

There is much evidence for Mande superiority (Childs 1997). One factor was the prestige and wealth of the early traders. Another was the knowledge of utensil- and weapon-making, along with the fact that the smiths were believed to possess magical powers. The Mande newcomers also brought along or founded a number of power associations such as Komo, Simo, Poro, and Sande/Bunde (Brooks 1993:73). The later Mandeng warriors were physically superior with their horses, weapons, and military conquests. As part of their campaign, they 
would enlist the men they conquered as soldiers or slaves. Furthermore, speakers of Mande languages kept aloof; they were reluctant to assimilate fully to the resident culture, especially those who followed Islam. Finally, Mande speakers were superior in that they typically lived in towns, and even founded a few towns themselves.

The cultural effects of Mande contact and superiority can similarly be characterized. The power associations they installed and controlled (with themselves at the top) were one instantiation of the hierarchical social structure replacing the flatter, more egalitarian structures traditionally found among Atlantic peoples (Fairhead et al. 2003). Various cultural artifacts and institutions were introduced, for example the marabouts or morimen. The switch from matrilineal to patrilineal societies is another result (Niane 1989). These examples all attest to the overweening influence of Mande culture on the Atlantic peoples. The influence also extends to language.

Linguistically the groups have been said to be typological opposites (e.g. Wilson 1989), but that statement needs revision in light of current findings (Childs 2002, 2004a), much of which was reported at a recent workshop ("Documenting convergence and diversity - Mande and Atlantic languages in contact", SOAS, University of London, September 6-9 2008). There are shared features which are attributable to contact, of the sort characterized socioculturally above. There have been intense periods of contact, and because of the asymmetrical control of power and resources, the influence has gone largely one way, from Mande languages to Atlantic languages. Thus, in the Mande-Atlantic interactions we see many of the results of contact found elsewhere on the continent. What makes this case particularly informative is that it takes place independently of European contact and thus could be representative of other unreported, totally African phenomena.

The general consequences of these socio-historical factors can be seen in a number of changes in these languages, as well as in the march towards language death by many of Atlantic's members. I begin by looking in detail at borrowings into Kisi.

\subsection{Linguistic effects}

In Kisi one can speak of both micro- and macro-linguistic effects. The former include specialized vocabulary in such areas as war-medicine, political divisions and positions, and power societies. The macro-linguistic effects include bilingualism, language maintenance with interference, and language shift. One obvious effect is the nature of the borrowing that has taken place. I have looked in detail at this phenomenon only in Kisi, but I can add to this statement some observations about what has happened to the three dying languages Mani, Kim, and Bom.

\subsubsection{Borrowing}

The semantics of the words borrowed from Mande into Kisi reflects the nature of the contact and supports what little we know of the history of the area. It also says something about how relations have changed since the advent of the Mandeng horse warriors.

Kisi has borrowed over 200 words from Mande in a Kisi lexicon of 5800 words (3.5\%), from which count proper nouns (people and towns) have been excluded. Specific examples and many more details can be found in Childs 2002 and Childs 2004b. Most borrowings are nominals but some are verbs, connectives, and bound morphemes. Somewhat controversially S-Aux-O-V word order has been said to have been borrowed (Güldemann 2008, questioning Childs 2004; Hyman 2010). Semantic borrowings include some "basic vocabulary", but most borrowings are in the areas of politeness formulae, family relations, political organization, commerce and trade, and religion.

The generalization characterizing the pattern of borrowings is that contact with speakers of Mande languages was accompanied by some complexification of life-Kisi society became much less "local" as roles and interactions increased. The Kisi were exposed to life beyond the confines of the village or hamlet (see Paulme 1954). 
In Table 1 are the several distinct stages in the borrowing process, correlating with the historical contact periods outlined in section 2.1.2. To each of these periods at least some of the semantic fields (from Table 2) can be assigned. Words having to do with trade, smithing, and secret societies probably belong to the first period; this would include, for example, the fields of commerce and finance, numbers; smithing and metal objects; and words particular to initiation societies and cultural events.

\section{Table 1: Layers of borrowing in Kisi}
Periods
Source
Semantic field
I. Early, pacific ( $8^{\text {th }}$ on $)$
General Mande
trade, smithing, secret societies
II. Military $\left(15^{\text {th }}-16^{\text {th }}\right)$
Mandeng
political and social organization
III. Islam, proselytizing
Mandeng
religious terminology
IV. Modern, culture sharing
South-West Mande
clothing, foods

Table 2 shows the semantic fields in which many borrowings can be placed. In the first column is a convenient name, in the second is the total number of words borrowed, and in the third appears the period during which the words were likely borrowed, as laid out in Table 1. The semantic fields with question marks are those which cannot be assigned to a period in any obvious way; most of them, however, do point in the direction of cultural complexification ("abstractions", foods and plants, etc.).

Table 2: Semantic fields of borrowings into Kisi

\section{Semantic field}

Politeness expressions

Family relations, titles

Political terms

Legal terminology

Commerce and finance, numbers

"Abstractions"

Foods and plants

Animals

Implements, articles of daily use

Clothing, hairstyles

Smithing, metal objects

Musical instruments, toys and games

Initiation societies, cultural events

Physical states, body parts, health

Religious terminology (Islam)

Discourse words

Ideophones, expressive forms

Miscellaneous

$\begin{array}{cc}\begin{array}{c}\text { No. of } \\ \text { borrowings }\end{array} & \text { Period } \\ 9 & \text { I? } \\ 11 & \text { I/II } \\ 14 & \text { II } \\ 8 & \text { II? } \\ 16 & \text { I } \\ 12 & ? \\ 20 & ? \\ 18 & ? \\ 24 & \text { IV } \\ 6 & \text { IV } \\ 7 & \text { I } \\ 8 & \text { IV } \\ 9 & \text { I } \\ 14 & ? \\ 7 & \text { III } \\ 7 & \text { IV? } \\ 14 & \text { IV } \\ 12 & \end{array}$




\subsubsection{The distribution of tone}

One remarkable feature of North and South Atlantic is the uneven and patterned distribution of tonal languages. In Childs (1995b) I analyzed the prosodic systems of twentythree Atlantic languages, classifying each into the categories given in Table 3. With regard to categories 2 and 4, for a language to be considered "Tone with some accent", tone must be at least lexical with some configurations or environments interpretable as accent. The mirror image (category 4) is much more straightforward; when a language has only "some tone", tone is restricted to only a few lexical contrasts.

Table 3: Accent and tone in Atlantic

$\begin{array}{lll}\text { 1. Unambiguously tonal } & 7 \\ \text { 2. Tone with some accent } & 3 \\ \text { 3. } & \text { Both tone and accent } & 2 \\ \text { 4. Accent with some tone } & 3 \\ \text { 5. Unambiguously accentual } & 8\end{array}$

The disappearance of tone in Atlantic has been regarded as unusual (Hombert 1984) and rightly so, but it is not an impossible occurrence, for it follows the more gradual changes from tone to accent in Bantu (Hyman 1978; Odden 1985, 1995). Generally, the languages which retained tone were those most in contact with Mande languages - virtually all of which are unambiguously tonal. Thus, contact with speakers of Mande languages may have been responsible for the retention of tone in Atlantic.

\subsubsection{Split predicates, the $S$-Aux-O-V-X syntagm}

Other consequences are syntactic. The split predicate or S-Aux-O-V-X syntagm has been attributed to contact, since Mande languages are overwhelmingly $\mathrm{S}-\mathrm{Aux}-\mathrm{O}-\mathrm{V}$, and there are contact-induced examples of S-Aux-O-V elsewhere (Güldemann 2008). Kisi is the best known example of this structure, for the rest of Atlantic generally allows only pronominal objects between the auxiliary and the (lexical) verb, parallel to what is seen in the highly synthetic Bantu verb. The examples in (3) show a single argument splitting the predicate. The examples in (4) show two arguments moved between AUX and the verb.

(3) Kisi predicate split by a single argument

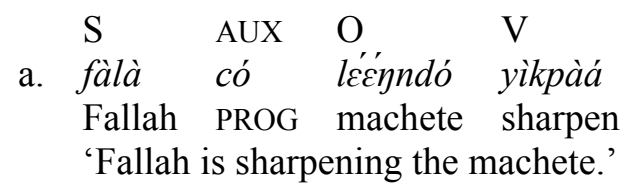

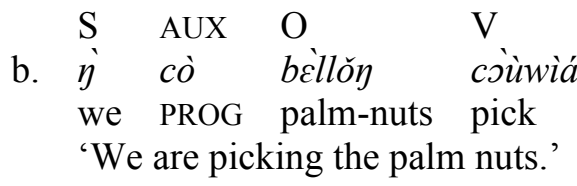

(4) Kisi predicate split by two arguments

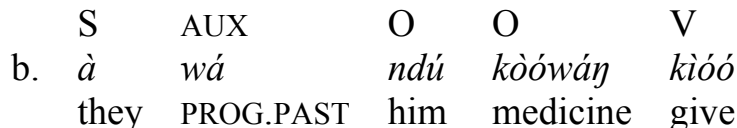
'They were giving him medicine.' 


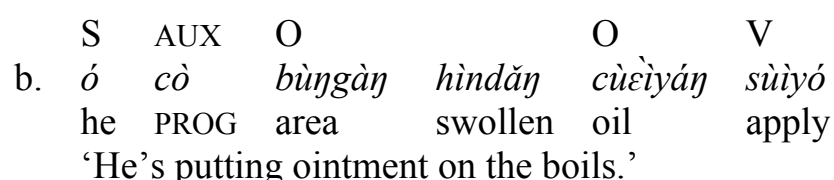

Childs (2003a) presents evidence of an internal scenario for the appearance of the "O" in a split predicate independent of contact. The basic argument is that most Atlantic languages allow pronouns in some form between auxiliary and verb, for example, Mani, Bom, and Gola in South Atlantic, the isolate Bijogo, and in North Atlantic, Wamei, Balanta, and the five Cangin languages. The languages vary as to which pronouns and where this movement is allowed, but in several cases even a noun is allowed between auxiliary and verb, as is robustly attested in Kisi. Thus the languages can be arranged in what Greenberg has called a "processural" arrangement, illustrating the process by which one structure changes into another (Greenberg 1969). The paper concludes, however, that contact with Mande could have been important in retaining the structure, and thus in either scenario we have a reference to contact with Mande affecting the syntax.

\subsubsection{Semantic structures}

One sort of structural transfer that takes place much more often than is documented is semantic structures. Both Brenzinger and Heine in public and private presentations (Heine 2003; Heine and Leyew 2008; Brenzinger 2003; Brenzinger and Dimmendaal 1992) have stressed the importance of this evidence for understanding the extent of the contact between languages (Ross 2007). A great deal of understanding has already been derived from pidgin and creole studies, such as the detailed work of Huttar (1993, 1994, 2002), the functional study of Childs (1994), and the whole Haitian Creole enterprise (Lefebvre 2004).

I present one example of calquing from the dying language Mani, where the transfer takes place from a Mande language to an Atlantic one for the plausible reason that Mani had no word for ' 100 '. The structure borrowed is the formal link between the word for ' 100 ' and 'stone'. The word kim ' ' 100 ' in Soso is the same as a general Mandeng root, a word which is homophonous with the word kime 'stones' in Soso, as shown in (5a). Mani has borrowed the homophony link to create its own word for ' 100 ', pé, from its own word for 'stone' pé, a good Atlantic stem with cognates in both Kim and Bom (line b.). In addition, as is also shown in (5b), Mani has also borrowed the Soso word itself ' 100 ', and thus has two different words for ' 100 ', where once it likely had none. Kisi has the Mande root as well (4c), but Bom has borrowed its word for '100' from English.)

(5) Calquing homophony in Mani
a. Soso ' 100 ' kغ̀mغ่
also 'stones' (general Mande stem, v. Maninka k'me)
b. Mani ' 100 ' pé
also 'stone' (cf. Kim/Bom pepe/pee 'stone')
kغ̀mè
c. Kisi ' 100 '
Bom ' 100 '
kémè
hundon
$<$ Eng. hundred

This example illustrates how deeply languages may borrow or transfer. In this particular case the transfer is from the Mande language Soso to a dying Atlantic language Mani. To 
import semantic structures in this way, speakers of Mani at the least are highly familiar with Soso; in actual fact today there are no monolingual speakers of Mani. ${ }^{9}$

\subsection{Sociolinguistic effects}

The four following sections exemplify the great variety of observed sociolinguistic effects of Atlantic-Mande contact.

\subsubsection{Language maintenance, diglossia, the Cangin languages}

That words are borrowed does not necessarily presage language shift or language death. Nowhere is this more prominently displayed than in the Wolof-speaking area of Senegal, where the Cangin languages are found in a relatively small area and have retained their viability over some time: language maintenance with stable bilingualism. An early report found that speakers of Cangin languages in Senegal spoke their languages only at home and were long considered to be speakers of Wolof, a much more widespread and politically important language (Pichl 1966). A later report, Williams (1994, based on 1986-87 fieldwork) offered an explanation in speakers' strong preference for the mother tongue. Similar observations come from a still later source:

\footnotetext{
Although there are very few monolinguals among the Cangin groups as a whole, the languages are still vital. With respect to one, Ndut, the total number of speakers is 21,000, with only 13,000 of them found in their historical place of origin. Almost a third are Catholic and the rest Muslim. Most children learn Wolof by the age of eight, which is the language of instruction in both churches and mosques. There are few monolinguals, yet Ndut remains the language of the home and intimate interpersonal relationships (Morgan 1996:1-2).
}

A more recent assessment (Drolc 2003) characterizes the situation as being one of prolonged stable bilingualism. The case of the Cangin languages, however, represents an exception, as will be seen in the following sections.

\subsubsection{Restructuring and simplification in Mande languages}

Extravagant claims have been made in the historical literature that there has been restructuring of and language shift to Atlantic languages on the part of the Mande overlords (Thomas $(1919,1920)$ as referenced in Rodney (1967:230)). Not enough of the structural consequences have been presented, and given the historical facts such scenarios are highly unlikely. The notion that "the Mendes represent the Mane fusion with the Bulloms and the Kissi, while the Lokos represent the same Mane elements fused with Temne [(Rodney 1967:237] is, in terms of linguistic history at least, jejune and misconceived" (Hair 1968:54). There were simply not enough speakers of Mande languages to have a structural effect on an Atlantic language, even including the newly recruited soldiers who spoke a Mande variety imperfectly as a second language. What is more likely, however, is a change in the various Mandeng varieties forming part of the later, more militant Mande Expansion. The invading army needed more soldiers as it advanced and impressed the conquered locals into their ranks. These second-language speakers likely simplified the variety they learned as part of their "enlistment". Bird (1970) has suggested that the homogeneity of the Mandeng languages is due to the fact that they have undergone simplification in the mouths of second language speakers (Dwyer 1972; 1975; 2005).

\footnotetext{
${ }^{9}$ No other examples could be identified that were distinct from areal structures which also show up in resident pidgins (Ross 2007), who faces a similar problem in identifying Takia calquing and metatypy.
} 


\subsubsection{Language shift and language death in Atlantic}

One area where scholarship has recently been particularly intense is on endangered languages, another consequence of language contact. Such varieties abound in Africa and indeed in Atlantic, despite the somewhat glib assessments below (also see Sommer 1992).

\footnotetext{
Languages in Africa appear to have a high survival rate, and even today very few languages are in imminent danger of extinction (Dalby 1988:93).

West African languages are generally holding their own in the face of globalisation and the homogenising forces of the twenty-first century (Blench 2007:156).
}

Not discussed here is Atlantic to Atlantic shifting. There are numerous cases of people who speak the less widely spoken languages shifting to the more widely spoken Atlantic languages Wolof, Fulfulde, and Temne. In this section I will discuss Atlantic speakers shifting to Mande languages, concentrating on South Atlantic and language death. The generalization is this: those groups who did not adopt Mande ways are likely to do so soon and abandon their language and culture, as summarized in 3.1.2, and elaborated in Childs (1999).

Before I present the overall picture of language shift and death, I would like to present one case of language shift, namely Temne, because the language shifted from still has many speakers. I also wish to clarify the record on (Ma)Banta/Banda, first reported in Dalby (1963). The variety was variously reported as a distinct language but also as a dialect of Temne. The recent work of Martin Kailie, a former lecturer at Fourah Bay College in Sierra Leone, confirms that "Banda" is indeed a special dialect of Temne, albeit much influenced by Mende, used primarily for ritual purposes, yet still a form of Temne, the language from which the present-day speakers originally switched. It is also the case that Banda users speak a recognizably Temne-accented variety of Mende, although none of them actually speaks Temne. Thus, we have a somewhat attenuated case of language maintenance without language death in a situation of language shift, a rather exceptional case among the smaller linguistic groups of Atlantic. We see the relic of a variety (Temne) being maintained by remaining functionally distinct. Perhaps even more surprisingly, the old men still using it maintain their Temne identity by not speaking a standard Mende.

Other Atlantic varieties continue in a limited function as religious or ritual languages. For example, Voeltz (2000 p.c.) reports on how some languages persist because they are the ones used to propitiate the ancestors, the original owners of the land. In my own research in Guinea, I was told rather disparagingly that Mani was used for talking to the ancestors and dogs. Another context in which languages might be preserved in a diglossic situation is in court languages, e.g. the Musanda variety of Tshivenda (Khuba 1990), see Schuh n.d. Unfortunately in the non-hierarchical societies of the less widely spoken Atlantic languages and their marginalized speakers, there is no such hierarchy nor any such leisure class. In sum, there seems little hope for most dying languages of Atlantic, since there are few possible special diglossic niches for their preservation, especially when the cultures with which the languages are associated are publicly mocked.

Figure 4 shows the degree to which languages are threatened. Language names in italics are languages that are not threatened; languages in bold are seriously threatened and will die in the near future. Languages in normal font are something in between, likely also doomed but not so immediately. At the bottom of the figure are the documented cases of language death (underlined). 
I. Northern Branch

A. Senegambian languages: Fulfulde, Serer; Wolof

B. Cangin: Lehar, Safen, Non; Ndut, Palor

C. Bak

1. Diola: Bandial, Bayot, Ejamat, Elun, etc. ${ }^{10}$ (All but Jola-Fogny and JolaKasa)

2. Manjaku, Mankanya, Papel

3. Balanta

D. Eastern Senegal-Guinea

1. Tenda: Tenda Mayo, Basari; Onian, Bedik; Konyagi

2. Biafada, Badiaranke

3. Buy, Kasanga, Bainouk

E. Nalu: Nalu, [tfilónit $f]$ (Mbulungish, Baga Fore), Pukur

II. Bijogo

III. Southern Branch
A. Mansoanka (Sua, Kunant)
B. Mel languages
1. Baga: Temne; Landuma, Baga, etc.
2. Bullom languages: Kisi; Mani, Sherbro, Kim, Bom
3. Gola
C. Limba

Dead: Baga Kalum (and other Baga languages), Mo-peng, Sei (?)

Figure 4: Language death in Atlantic (Childs 2009)

Numbers of speakers are shown in Table 4. For the most part the numbers come from Ethnologue (Gordon 2005), except where they are known to be inaccurate either by myself or by fieldworkers currently working with the languages, e.g. Bradley Hopkins in Senegal, Hans Fritz in Guinea-Bissau. The names given for each language correspond to those used in Figure 4, except in a few cases where Ethnologue over-differentiates, e.g. Balanta is one language above but separated into two by Ethnologue. Names in parentheses are Ethnologue names followed by their identifiers. The heavy double line separates what have been considered viable languages (more than 100,000 speakers) from those that are not. The lighter double line separates languages at the 500,000-speaker divide, likely a more significant separator for Atlantic. ${ }^{11}$

\footnotetext{
${ }^{10}$ Not all Diola languages are included here because of the sub-group's uncertain constituency; the same is true for the Baga sub-group in the Southern Branch.

${ }^{11}$ In his database of West African languages Blench assumes a cut-off point of 50,000 as signifying a language is "not threatened" (Blench 2007:143). It is impossible to posit an exact number due to the varying circumstances ( $c f$. Sommer 1992).
} 
Table 4: Numbers of speakers of Atlantic languages

More than a million Fula/Fulfulde (Pulaar, fuc; Pular, fuf), Seereer (Serer-Sine, srr), Temne (tem), Wolof (wol, wof)

\begin{tabular}{ll}
\hline 500,000-million & [N.B. no languages of this size] \\
\hline $100,000-500,000$ & Balanta (Balanta-Kentohe, ble), Diola-Fogny (Jola Fonyi, dyo), Kisi \\
& (Kissi, Northern, kqs; Kissi Southern, kss), Limba (Limba, East, lma; \\
& Limba, West Central, lia), Manjaku (Mandjak, mfv), Papel (pbo), \\
& Safen (Saafi-Saafi, sav), Sherbro (bun)
\end{tabular}

50,000-100,000 Balanta-Ganja (bjt), ${ }^{12}$ Gola (gol)

25,000-50,000 Biafada (bif), Bijogo (Bidyogo, bjg), Diola Kasa (Jola Kasa, csk), Ejamat (eja), Mankanya (knf), Ndut (ndv), Noon (snf)

10,000-25,000 Badiaranke (Badyara, pbp), Basari (Bassari, bsc), Bayot (bda), Gusilay (gsl) ${ }^{13}$, Kerak (hhr), Mansoanka (msw), Nalu (naj), Konyagi (Wamey cou)

5,000-10,000 Bainouk (Bainouk-Gunyuño, bab), Karon (krx), Kuwaataay (cwt), Lehar (cae), Palor (fap)

1,000-5,000 Baga Koga (bgo) ${ }^{14}$, Baga Manduri (bmd), Baga Mboteni (bgm), Pukur (Baga Binari bcg), Bandial (bqj), Bedik (Budik, tnr), Ejamat (eja), Baga Sitemu (bsp)

$500-1000$ Kasanga (ccj), Buy (Kobiana kcj)

$100-500$

Less than 100 Buy (Kobiana, kcj), Mani (Bullom So, buy), Mlomp (mlo)

Zero Kim (krm), Bom, Sei Baga Kalum (and some other Baga languages), Mo-peng

The numbers are probably lower than those indicated here, for in some cases Ethnologue gives only ethnic numbers. Furthermore, the numbers for Mani, Kim, and Bom given in Ethnologue are too high on the basis of my own recent fieldwork (2004-06, 2007-09), raising the suspicion that numbers for other languages are also inaccurate.

One noticeable feature of the display is the bulk of languages in the bottom part of the table: at least two languages are dead; three have less than a hundred speakers, three less than 500 , and so on. Note also that the heavy line represents the cut-off point for languages that are generally thought to be endangered (Krauss 1992). What is further remarkable about this display is the vast gap between 500,000 and a million represented by the lighter line. What is ironic is that in many cases the doomed languages are losing speakers to the more widely spoken languages above the heavy line.

\subsubsection{Language shift from Mande to Atlantic}

In only a few instances do we find speakers of Mande languages shifting to Atlantic languages. In all cases the circumstances are somewhat unusual and reinforce the general patterns found elsewhere. The three major Atlantic languages, Wolof, Fulfulde, and Temne, are all gaining speakers from the less widely spoken languages. Loko, a Southwestern Mande language close to Mende, one of the major predatory Mande languages of Sierra Leone, is losing speakers to Temne, just as is the dying Atlantic language Mani. Nonetheless, Loko is in no danger of immediately disappearing. It has over 100,000 speakers as opposed to Mani, which has just a few hundred.

\footnotetext{
${ }^{12}$ Ethnologue considers Balanta-Ganja to be a distinct language from Balanta-Kentohe.

${ }^{13}$ Gusilay is one of the "etc." languages in the Diola sub-group in Figure 4. The others are Karon, Kuwaataay, Kerak, and Mlomp.

14 This is one of several Baga languages represented as "etc." in Figure 4. Several others are Baga Manduri and Baga [t $\mathrm{t}$ item] / Sitem. Two languages in the Nalu sub-group are known in the literature as "Baga _" languages: Pukur and [tfilónitf], but do not form part of the Baga sub-group (see Voeltz 1996).
} 
Both Wolof and Fulfulde are also acquiring speakers, primarily from the less widely spoken languages. In one case the shift is from a Mande language: Jalonke (Yalunke, ISO 639-3: yal) speakers are shifting to Fulfulde, probably as a consequence of the Jalonke people being enslaved by the Fula (see Lüpke 2005).

Very few Mande languages are threatened (Valentine Vydrine 2005 p.c.; Raimund Kastenholz 2005 p.c.; Kastenholz 1998). Vydrine was able to name only two: Shange and Tyenga in NW Nigeria, with the others doing well. On the basis of information from Ethnologue, the factors affecting threatened Mande languages are similar to those affecting Atlantic: the appeal of more widely spoken languages and, probably, religion (Islam).

\section{Conclusion}

This paper has presented some examples of contact phenomena in West Africa, looking at contact between the Mande group of languages and Atlantic. It has examined both the microlinguistic consequences as well as the causes and effects on a societal and macro-linguistic level. The generalization about the identified contact is that it is has largely been a one-way phenomenon. Mande superiority, especially in the later, more militaristic stages, has led to borrowings and transferred features in Atlantic languages, language shift, and in many cases, language death.

However, I suggest that the explanation is probably more complex. Additional factors, including such cultural practices as the welcome given to outsiders or strangers (Shack and Skinner 1979), also contribute, as stated elsewhere (Childs 2009). Another factor not discussed here is the West African openness to and prevalence of multilingualism (Grinevald 2007). Speaking more than one language has been the norm in Africa for a long time, particularly in Sub-Saharan Africa above the Congo rain forest (Güldemann 2008). Multilingualism results from the movement of peoples as well as from well-established routes of communication and trade (Wilmsen 1981). The linguistic result of this has been what has been called the "Fragmentation Belt" (Dalby 1970:167; Westermann 1911), discussed above. Multilingualism has been called a part of "African language ideology", an acceptance or belief in two or more languages in one's repertoire being assigned to different social contexts (Grenoble and Whaley 1998:44). This, of course, means that there is not the rabid nationalist devotion to language found elsewhere in the world (pace Obeng and Adegbija 1999).

That there is much work to be done is obvious. The emphasis of future research, however, should be on the socio-historical and non-linguistic side, reinforced, of course, by linguistic data. I have indicated above what directions such research has taken and below what directions it could take. These all tend towards language documentation, e.g. Austin (2006), Austin and Grenoble (2007), and "rich" or "thick" description that situates a language in a socio-cultural and historical context.

On the historical side, linguists need to become better informed about the contexts in which contact between Mande and Atlantic speakers took place. Models of such research occur in other parts of the continent, for example, Dimmendaal (1998), Mous (2003), and Kiessling et al. (2008). In the last work, for instance, we are generously provided with historical dates, population figures, data on changes in the groups' size, as well as the types of societies and prestige and power relations (pp. 187-89).

In most research on the Mande-Atlantic interface, on the other hand, we are provided merely with the linguistic contact information, rarely of the stratographic sort, e.g. Huttar (1994), and left to infer the history. One great disadvantage in working on Mande-Atlantic interactions is that little history is known beyond a few generations back, especially among the less widely spoken and under-researched Atlantic languages. There are no Atlantic griots, epic traditions, or other historical genres, to assist us, however much the veracity of those genres may be suspect, molded by changes in leaders and power relations (Belcher 1999).

Therefore, other techniques will have to be used, as demonstrated by Blench (2006) and Nettle $(1996,1998)$. What few archaeological findings exist may furnish some insights, and 
comparative ethnography is another technique. DNA testing, in use since the 1990s, is an important resource when used with some caution. The "ecological approach" of Nettle is another fine example of innovative techniques in explaining language diversity. Using correlational statistics and topographical mapping, he shows,

... that ecological risk has been a key historical force in West Africa and that the ethnolinguistic mosaic can be used as a valuable "fossil record" of people's adaptive social and economic strategies (Nettle 1996).

In short, if linguists can become more open to findings and techniques from related fields, the progress in understanding both current and historical cases of language contact will be considerable. 


\section{Appendices}

\section{Appendix 1: Atlantic classified (Childs 2004a)}

$(\mathrm{n}=43)$

The display below shows the generally accepted classification of Atlantic, the isolate Bijogo and the two geographical branches. The Northern Branch is by far the largest, containing some thirty-plus languages, and the Southern Branch contains around twelve.

I. Northern Branch
A. Senegambian languages
1. Fulfulde, Seereer
2. Wolof
B. Cangin: Lehar, Safen, Noon; Ndut, Palor
C. Bak
1. Diola

a. Bayot-Essin

b. Diola Proper

1) Karon, Kwatay

2) Diola, Gusilay, Kasa

3) Ediamat, Mlomp, Her

2. Manjaku, Mankanya, Papel

3. Balanta

D. Eastern Senegal-Guinea

1. Tanda: Onian, Wamei

2. Biafada, Badyara

3. Buy, Kasanga; Bainouk

II. Bijogo

III. Southern Branch
A. Mel languages
1. Temne; Baga Maduri, Baga Tfitem, Lonitf, Baga Koba, Landoma
2. Bulom languages: Kisi; Mani, Sherbro, Kim, Bom
3. Gola
B. Limba

\section{Appendix 2: Atlantic classified (Gordon 2005)}

$(\mathrm{n}=64)$

Bijago (1): Bidyogo [bjg] (Guinea-Bissau)

Northern (45)

Bak (15)

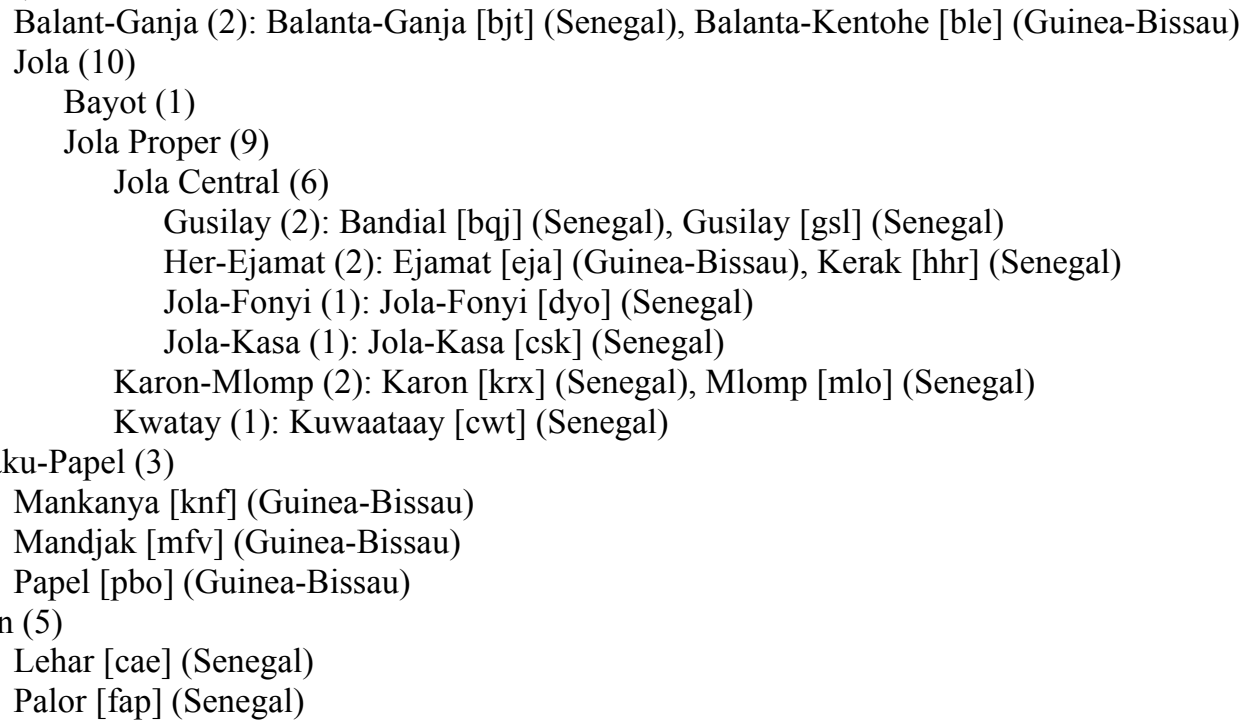


Ndut [ndv] (Senegal)

Saafi-Saafi [sav] (Senegal)

Noon [snf] (Senegal)

Eastern Senegal-Guinea (10)

Banyun (3)

Bainouk-Gunyuño [bab] (Guinea-Bissau)

Bainouk-Samik [bcb] (Senegal)

Bainouk-Gunyaamolo [bcz] (Senegal)

Nun (2): Kasanga [ccj] (Guinea-Bissau), Kobiana [kcj] (Guinea-Bissau)

Tenda (5)

Biafada [bif] (Guinea-Bissau)

Bassari [bsc] (Senegal)

Wamey [cou] (Senegal)

Badyara [pbp] (Guinea)

Budik [tnr] (Senegal)

Mbulungish-Nalu (3)

Baga Mboteni [bgm] (Guinea)

Mbulungish [mbv] (Guinea)

Nalu [naj] (Guinea)

Senegambian (12)

Fulani-Wolof (9)

Fula (9)

East Central (3)

Fulfulde, Western Niger [fuh] (Niger)

Fulfulde, Central-Eastern Niger [fuq] (Niger)

Fulfulde, Nigerian [fuv] (Nigeria)

Eastern (2): Fulfulde, Adamawa [fub] (Cameroon), Fulfulde, Bagirmi [fui] (Chad)

West Central (3)

Fulfulde, Maasina [ffm] (Mali)

Fulfulde, Borgu [fue] (Benin)

Pular [fuf] (Guinea)

Western (1): Pulaar [fuc] (Senegal)

Fula-Wolof (2)

Wolof (2): Wolof, Gambian [wof] (Gambia), Wolof [wol] (Senegal)

Serer (1): Serer-Sine [srr] (Senegal)

Southern (18)

Sua (1): Mansoanka [msw] (Guinea-Bissau)

Limba (2): Limba, West-Central [lia] (Sierra Leone), Limba, East [1ma] (Guinea)

Mel (15)

Bullom-Kissi (6)

Bullom (4)

Northern (2): Bom [bmf] (Sierra Leone), Bullom So [buy] (Sierra Leone)

Southern (2): Sherbro [bun] (Sierra Leone), Krim [krm] (Sierra Leone)

Kissi (2): Kisi, Southern [kss] (Liberia), Kissi, Northern [kqs] (Guinea)

Gola (1): Gola [gol] (Liberia)

Temne (8)

Baga (7)

Baga Binari [bcg] (Guinea)

Baga Koga [bgo] (Guinea)

Baga Manduri [bmd] (Guinea)

Baga Kaloum [bqf] (Guinea)

Baga Sitemu [bsp] (Guinea)

Baga Sobané [bsv] (Guinea)

Landoma $[\mathrm{ldm}]$ (Guinea)

Temne-Banta (1): Themne [tem] (Sierra Leone) 


\section{Appendix 3: Mande classified (Gordon 2005)}

$(\mathrm{n}=71)$

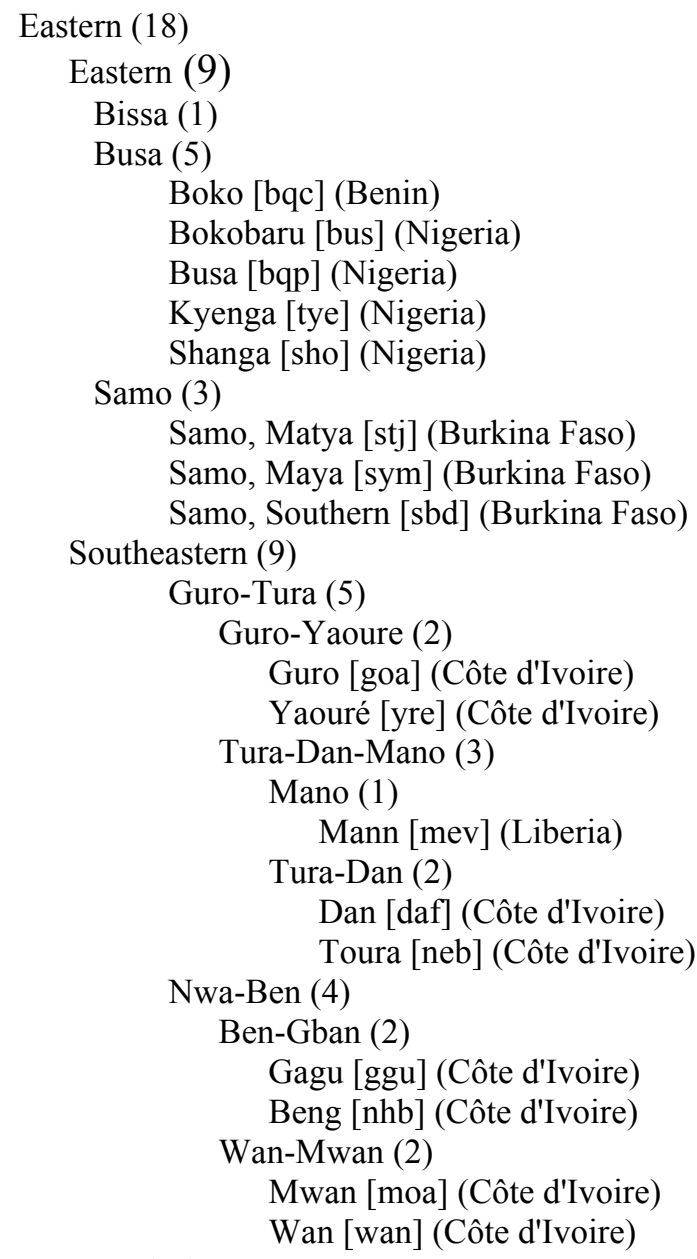

Western (53)

Central-Southwestern (41)

Central (33)

Manding-Jogo (31)

Jogo-Jeri (4)

Jeri Kuo [jek] (Côte d'Ivoire)

Jeri-Jalkuna (1)

Jalkunan [bxl] (Burkina Faso)

Jogo (2)

Ligbi [lig] (Ghana)

Tonjon [tjn] (Côte d'Ivoire)

Manding-Vai (27)

Manding-Mokole (25)

Manding (21)

Bolon [bof] (Burkina Faso)

Jahanka [jad] (Guinea)

Manding-East (13)

Marka-Dafin (1)

Marka [rkm] (Burkina Faso)

Northeastern Manding (2)

Bamana (2)

Southeastern Manding (10)

Maninkakan, Eastern [emk] (Guinea)

Maninka-Mori (6)

Maninka, Konyanka [mku] (Guinea) 


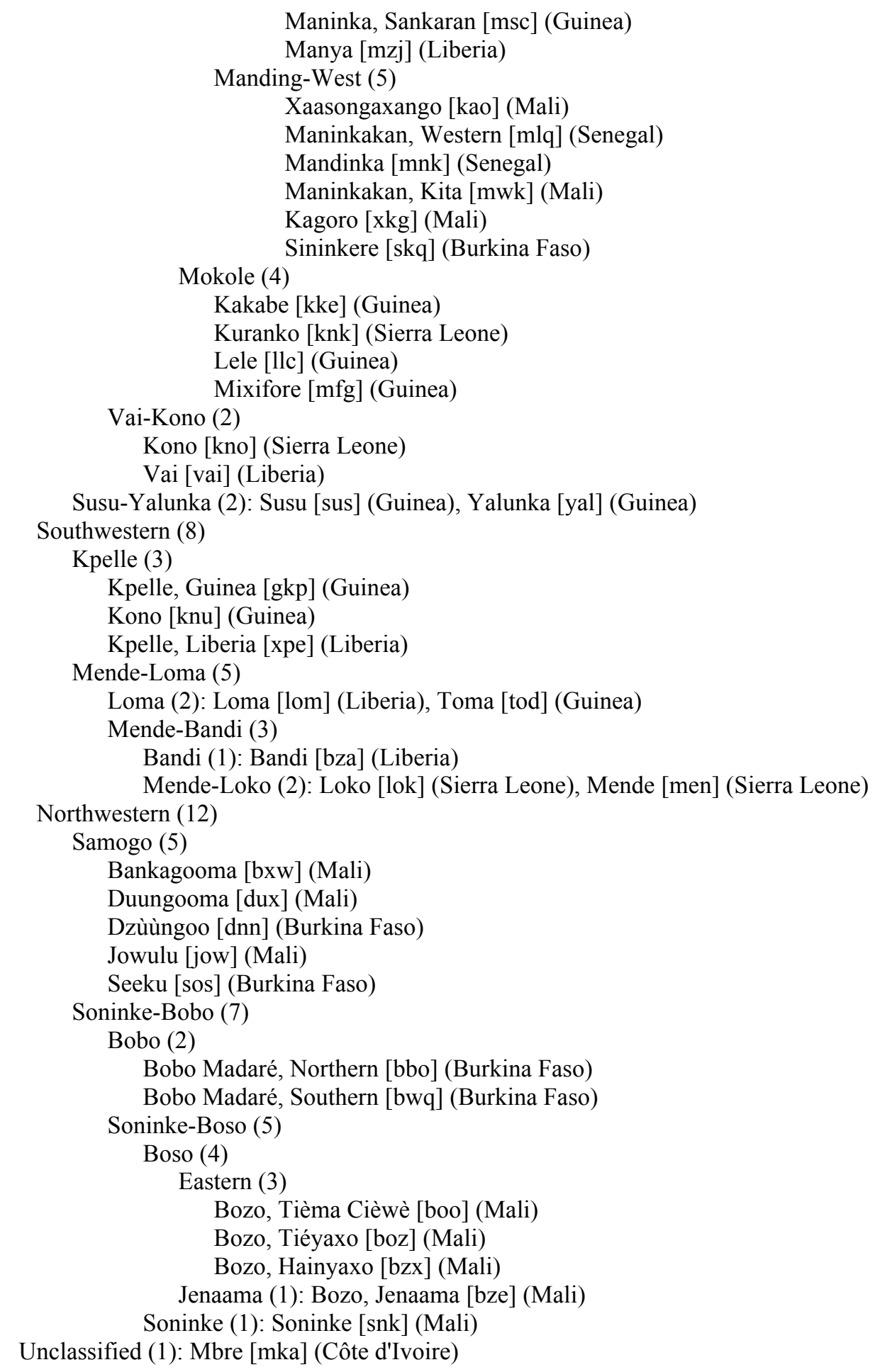




\section{References}

Aikhenvald, Alexandra Y. and Robert M. W Dixon. 2001. Introduction. In: Alexandra Y. Aikhenvald and R. M. W. Dixon. (eds.). Areal diffusion and genetic inheritance: Problems in comparative linguistics. Oxford, UK: Oxford University Press, 1-26.

Austin, Peter K. 2006. Data and language documentation. In: Jost Gippert, Nikolaus P. Himmelmann and Ulrike Mosel. (eds.). Essentials of language documentation. Berlin: Mouton de Gruyter, 87-112.

Austin, Peter K. and Lenore Grenoble. 2007. Current trends in language documentation. In: Peter K. Austin. (ed.). Language Documentation and Description 4. London: Hans Rausing Endangered Languages Project, School of Oriental and African Studies (SOAS), 12-25.

Bassène, Alain-Christian. 2007. Morphosyntaxe du jóola banjal, langue atlantique $d u$ Sénégal. Köln : Köppe.

Belcher, Stephen (ed.). 1999. Epic traditions of Africa. Bloomington, IN: Indiana University Press.

Bennett, Patrick R. and Jan P. Sterk. 1977. South Central Niger-Congo: a reclassification. Studies in African Linguistics 8:241-273.

Bimson, K. 1978. Comparative reconstruction of Proto-Northern-Western Mande. Ph.D. thesis, Linguistics, University of California, Los Angeles.

Bird, Charles S. 1970. The development of Mandekan (Manding): a study of the role of extralinguistic factors in linguistic change. In: David Dalby. (ed.). Language and history in Africa. New York: Africana Publishing Company, 146-159.

Blench, Roger M. 1999. Why is Africa so linguistically undiverse compared with Papua and Australia?: Revised paper originally presented at ANU Canberra (Australian National University) on 30 ${ }^{\text {th }}$ July 1999 in Dept of Archaeology and Anthropology:1-17.

Blench, Roger M. 2006. Archaeology, language, and the African past. Lanham, MD: AltaMira Press.

Blench, Roger M. 2007. Endangered languages in West Africa. In: Matthias Brenzinger (ed.). Language diversity endangered. The Hague: Mouton de Gruyter, 140-162.

Brenzinger, Matthias. 2003. Vanishing concepts and language documentation: changing meanings in Khwe. New Brunswick, N.J. : Rutgers University, World Congress of African Linguistics (WOCAL 4).

Brenzinger, Matthias and Gerrit J. Dimmendaal. Social contexts of language death. In: Matthias Brenzinger. (ed.). Language death: factual and theoretical explorations with special reference to East Africa. 3-5. Berlin - New York: Mouton de Gruyter.

Brenzinger, Matthias, Bernd Heine and Gabriele Sommer. 1991. Language death in Africa. In: Robert H. Robins and Eugenius M. Uhlenbeck. (eds.). Endangered languages. Oxford - New York: Berg Publishers Ltd, 19-44.

Brooks, George E. 1993. Landlords and strangers: ecology, society, and trade in western Africa, 1000-1630. Boulder, CO : Westview Press.

Bühnen, Stephan. 1994. Geschichte der Bainunk und Kasanga. Doktors der Philosophie thesis, Fachbereich Geowissenschaften und Geographie, Justus-Liebig-Universität Giessen.

Calvet, Louis-Jean. 1974. Linguistique et colonialisme: petite traité de glottophagie. Paris : Payot. 
Childs, G. Tucker. 1994. Expressiveness in contact situations: the fate of African ideophones. Journal of Pidgin and Creole Languages 9:257-282.

Childs, G. Tucker. 1995a. A grammar of Kisi: A Southern Atlantic language. Berlin - New York: Mouton de Gruyter.

Childs, G. Tucker. 1995b. Tone and accent in the Atlantic languages: an evolutionary perspective. In: Anthony Traill, Rainer Vossen and Megan Biesele. (eds.). The complete linguist. Papers in memory of Patrick J. Dickens. Köln: Köppe, 195-215.

Childs, G. Tucker. 1997. Prosodic typology and language change: the role of social factors in West Africa. In: $27^{\text {th }}$ Colloquium on African Languages and Linguistics. Leiden.

Childs, G. Tucker. 1999. Social factors favoring the retention of tone in the Atlantic languages of West Africa. In: $29^{\text {th }}$ Colloquium on African Languages and Linguistics. Leiden.

Childs, G. Tucker. 2001. What's so Atlantic about Atlantic?. In: $31^{\text {st }}$ Colloquium on African Languages and Linguistics. Leiden.

Childs, G. Tucker. 2002. Borrowings into Kisi as evidence of Mande expansionism and influence. Journal of West African Languages 29-2:81-120.

Childs, G. Tucker. 2003a. Genetic or areal? The S-Aux-O-V syntagm in the Atlantic languages. In: World Conference on African Linguistics 4 / Annual Conference on African Linguistics 34. Rutgers University, East Brunswick, NJ.

Childs, G. Tucker. 2003b. An introduction to African languages. Amsterdam - Philadelphia: John Benjamins.

Childs, G. Tucker. 2003c. A splitter's holiday: More on the alleged unity of the Atlantic Group. In: 33rd Colloquium on African Languages and Linguistics. Leiden.

Childs, G. Tucker. 2004a. The Atlantic and Mande groups of Niger-Congo: A study in contrasts, a study in interaction. Journal of West African Languages 30 (A special issue containing, H. Ekkehard Wolff. (ed.). Proceedings of an International Symposium: Areal typology of West African languages (Leipzig, Institut für Afrikanistik, University of Leipzig and Max Plank Institute, 2003), 2:29-40.

Childs, G. Tucker. 2004b. The S-AUX-O-V syntagm in the Atlantic languages. Studies in African Linguistics 33-2:1-41.

Childs, G. Tucker. 2008. Language death within the Atlantic group of West Africa. WARA Newsletter Spring 2008, 1, 14. (West African Research Association).

Childs, G. Tucker. 2009. Language contact in Africa, a selected review. In: Raymond Hickey. (ed.). Handbook of language contact. In press. Malden, MA - Oxford, UK: Blackwell Publishers.

Childs, G. Tucker. 2009. Language endangerment in West Africa: its victims and causes. Journal of African Language Learning and Teaching, In press.

Childs, G. Tucker. In press. A grammar of Mani. New York - Berlin: Mouton de Gruyter.

Clements, George N. and Annie Rialland. 2008. Africa as a phonological area. In: Bernd Heine and Derek Nurse. (eds.). A linguistic geography of Africa. Cambridge, UK: Cambridge University Press, 36-85.

d'Azevedo, Warren L. 1959. The setting of Gola society and culture some theoretical implications of variation in time and space. Kroeber Anthropological Society Papers 21:43-125. 
Dalby, David. 1966. Levels of relationship in the comparative study of African languages. African Language Studies 7:171-179.

Dalby, David. 1970. Reflections on the classification of African languages with special reference to the work of Sigismund Wilhelm Koelle and Malcolm Guthrie. African Language Studies 11:1-14.

Dalby, David. 1988. African languages. In: Africa south of the Sahara 1989: 93-96. London: Europa Publications Limited.

Dalby, T. D. P. 1962. Language distribution in Sierra Leone: 1961-62. Sierra Leone Language Review 1:62-67.

Dalby, T. D. P. 1963. Banta and Mabanta. Sierra Leone Language Review 2:23-25.

Delafosse, Maurice. 1924. Groupe Sénégalo-Guinéen. In: Antoine Meillet et Marcel Cohen. (éds.). Les langues du monde. Paris : Librairie Ancienne Édouard Champion.

Dimmendaal, Gerrit J. 1998. Surmic languages and cultures: An introduction. In: Gerrit J. Dimmendaal and Marco Last. (eds.). Surmic languages and cultures (Nilo-Saharan linguistic analysis and documentation 13). Köln: Köppe, 3-33.

Dimmendaal, Gerrit J. 2001. Areal diffusion vs. genetic inheritance: An African perspective. In: Alexandra Y. Aikhenvald and R. M. W. Dixon. (eds.). Areal diffusion and genetic inheritance: Problems in comparative linguistics. Oxford, UK: Oxford University Press, 358-392.

Dimmendaal, Gerrit J. 2008. Language ecology and linguistic diversity on the African continent. Language and Linguistics Compass 2-5:84-858.

Dixon, Robert M. W. 1997. The rise and fall of languages. Cambridge, UK: Cambridge University Press.

Doneux, Jean-Léonce. 2003. Histoire de la linguistique africaine. Aix-en-Provence : Publications de L'Université de Provence.

Drolc, Ursula. 2003. On the emergence of bidrectional vowel harmony in Ndut. Trenton, NJ: Rutgers University, World Congress of African Linguistics (WOCAL 4).

Ducos, Gisèle. 1979. Intégration d'emprunts malinké (groupe mande) au badiaranké (groupe ouest-atlantique) du Sénégal et de Guinée. Études Linguistiques 1:95-118.

Dwyer, David J. 1972. Linguistic comments on the Mane invasion. Freetown, Sierra Leone: Institute of African Studies, Fourah Bay College.

Dwyer, David J. 1975. Convergence and basic vocabulary: some interesting findings. Working Papers in Linguistics, Michigan State University 2:79-108.

Dwyer, David J. 1989. Mande. In: John Bendor-Samuel. (ed.). The Niger-Congo Languages. 47-66. Lanham, MD - London, UK: University Press of America, Inc.

Dwyer, David J. 2005. The Mende problem. In: Koen Bostoen and Jacky Maniacky. (eds.). Studies in African Comparative Linguistics with special focus on Bantu and Mande. 29-42. Tervuren: Musée Royale de l'Afrique Centrale.

Fairhead, James, Tim Geysbeek, Svend E. Holsoe and Melissa Leach. (eds.). 2003. AfricanAmerican exploration in West Africa: Four nineteenth-century diaries. Bloomington, IN: Indiana University Press.

Gordon, Raymond G. Jr. (ed.). 2005. Ethnologue: Languages of the world (15 ${ }^{\text {th }}$ ed.). Dallas, TX: SIL International. Online version: http://www.ethnologue.com/. 
Greenberg, Joseph H. 1959. Africa as a linguistic area. In: William R. Bascom and Melville J. Herskovits. (eds.). Continuity and change in African cultures. Chicago: University of Chicago Press, 15-27.

Greenberg, Joseph H. 1963. The languages of Africa. Bloomington, IN: Indiana University.

Greenberg, Joseph H. 1969. Some methods of dynamic comparison in linguistics. In: Jaan Puhvel. (ed.). Substance and structure in language (Lectures delivered before the Linguistic Institute of the Linguistic Society of America, University of California at Los Angeles, June 17 - August 12, 1966). Berkeley and Los Angeles: University of California Press, 147-203.

Grenoble, Lenore and Lindsay J. Whaley. 1998. Towards a typology of language endangerment. In: Lenore Grenoble and Lindsay J. Whaley. (eds.). Endangered languages: Language loss and community response. Cambridge, UK: Cambridge University Press, 22-54.

Grinevald, Colette. 2007. Encounters at the brink: linguistic fieldwork among speakers of endangered languages. In: Osahito Miyaoka, Osamu Sakiyama and Michael E. Krauss. (eds.). The vanishing languages of the Pacific Rim. Oxford, UK: Oxford University Press, 35-76.

Güldemann, Tom. 2008. The Macro-Sudan belt: towards identifying a linguistic area in northern sub-Saharan Africa. In: Bernd Heine and Derek Nurse. (eds.). A linguistic geography of Africa. Cambridge, UK: Cambridge University Press, 151-185.

Güldemann, Tom. (ed.). In preparation. Africa. The field of linguistics: A survey of linguistics research 1. Berlin: Mouton de Gruyter.

Hair, P. E. H. 1968. An ethnolinguistic inventory of the Lower Guinea Coast before 1700: Part 1. African Language Review 7:47-73.

Haspelmath, Martin, Matthew S. Dryer, David Gil and Bernard Comrie. 2005. The world atlas of language structures. Oxford, UK: Oxford University Press.

Heine, Bernd. 1997. Grammaticalization theory and its relevance to African linguistics. In: Robert K. Herbert. (ed.). African linguistics at the crossroads: Papers from Kwaluseni (1st World Congress of African Linguistics, Swaziland, 18-22 July). Köln: Köppe, 1-15.

Heine, Bernd. 2003. Is Africa a linguistic area? New Brunswick, NJ: Rutgers University World Congress of African Linguistics (WOCAL 4).

Heine, Bernd and Leyew, Zelealem. 2008. Is Africa a linguistic area? In: Bernd Heine and Derek Nurse (eds.). A linguistic geography of Africa. Cambridge, UK: Cambridge University Press, 15-35.

Heine, Bernd and Derek Nurse. (eds.). 2008. A linguistic geography of Africa. Cambridge, UK: Cambridge University Press.

Herbert, Robert K. and Thomas N. Huffman. 1993. A new perspective on Bantu expansion and classification: Linguistic and archaeological evidence fifty years after Doke. African Studies 52-2:37-61.

Hyman, Larry M. 2010. The Macro-Sudan Belt and Niger-Congo Reconstruction. Language Dynamics and Change 1, 1: In press.

Himmelmann, Nickolaus P. 2006. Language documentation: what is it and what is it good for? In: Jost Gippert, Nikolaus P. Himmelmann and Ulrike Mosel. (eds.). Essentials of Language Documentation. Berlin: Mouton de Gruyter, 1-30. 
Hombert, Jean-Marie. 1984. Les systèmes tonals des langues africaines: typologie et diachronie. Pholia 1:113-164.

Huttar, George L. 1993. Identifying Africanisms in New World languages: how specific can we get?. In: Salikoko S. Mufwene. (ed.). Africanisms in Afro-American language varieties. Athens, GA: University of Georgia Press, 47-63.

Huttar, George L. 1994. Lexical borrowing, creolization, and basic vocabulary. In: Susan C. Herring and John C. Paolillo. (eds.). UTA Working Papers in Linguistics. Arlington, TX: Program in Linguistics, University of Texas, 1-13.

Huttar, George L. 2002. Creole genesis: the nature and use of semantic and lexical evidence. San Francisco: SPCL annual meeting (Society for Pidgin and Creole Linguistics).

Hyman, Larry M. 1978. Tone and / or accent. In: Donna Jo Napoli. (ed.). Elements of tone, stress, and intonation. Washington, DC: Georgetown University Press, 1-20.

Kastenholz, Raimund. 1991/92. Comparative Mande studies: State of the art. Sprache und Geschichte in Afrika 12-13:107-158.

Kastenholz, Raimund. 1994. Beobachtungen an Sprachresten des Tonjon (West-Mande). In: Thomas Geider and Raimund Kastenholz. (eds.). Sprachen und Sprachzeugnisse in Afrika, eine Sammlung philologischer Beitraege Wilhelm J.G. Möhlig zum 60. Geburtstag zugeeignet. Köln: Köppe, 207-220.

Kastenholz, Raimund. 1998. Language shift and language death among Mande blacksmiths and leatherworkers in the diaspora. In: Matthias Brenzinger. (ed.). Endangered languages in Africa. Köln: Köppe, 253-266.

Kastenholz, Raimund. 2001. Le jèri.kúò (langue mandé des Jéri): répartition géographique et matériel lexical. Mandenkan 37:49-88.

Khuba, A. E. 1990. The diglossic nature of a language: the Musanda language of the Venda. Johannesburg: International Conference on "Sociolinguistics in Africa", 30 feb - 2 Feb 1990, University of the Witwatersrand.

Kiessling, Roland, Maarten Mous and Derek Nurse. 2008. The Tanzanian Rift Valley area. In: Bernd Heine and Derek Nurse. (eds.). A linguistic geography of Africa. Cambridge, UK: Cambridge University Press, 186-227.

Krauss, Michael. 1992. The world's languages in crisis. Language 68-1:4-10.

Kup, Peter. 1961. A history of Sierra Leone, 1400-1787. London: Cambridge University Press.

Lefebvre, Claire. 2004. Issues in the study of pidgin and creole languages. Amsterdam - New York: John Benjamins.

Lüpke, Friederike. 2005. A grammar of Jalonke argument structure. Ph.D. thesis, Max Planck Institute for Psycholinguistics, Nijmegen, Netherlands.

Morgan, Daniel Ray. 1996. Overview of grammatical structures of Ndut: A Cangin language of Senegal. M.A. thesis, Linguistics, University of Texas, Austin, TX.

Mous, Maarten. 2003. The making of a mixed language: The case of Ma'a/Mbugu. Amsterdam-Philadelphia: John Benjamins.

Mukarovsky, Hans G. 1976-77. A study of Western Nigritic (2 vols.). Vienna: Afro-Pub and Institut für Ägypotologie und Afrikanistik der Universität Wien.

Murdock, George Peter. 1959. Africa: its peoples and their culture history. London: McGraw-Hill. 
Nettle, Daniel. 1996. Language diversity in West Africa: an ecological approach. Journal of Anthropological Archaeology 15:403-438.

Nettle, Daniel. 1998. The Fyem language of Northern Nigeria. München: Lincom.

Newman, Paul. 1995. On being right: Greenberg's African linguistic classification and the methodological principles which underlie it. Bloomington: Institute for the Study of Nigerian Languages and Cultures, African Studies Program, Indiana University.

Newman, Paul. 2000. Comparative linguistics. In: Bernd Heine and Derek Nurse. (eds.). African Languages: An introduction. Cambridge: Cambridge University Press, 259272.

Niane, Djibril Tamsir. 1989. Histoire des Mandingues de l'ouest. Paris : Karthala et Arsan.

Obeng, Samuel Gyasi, and Efurosibina Adegbija. 1999. Sub-Saharan Africa. In: Joshua A. Fishman. (ed.). Handbook of language and ethnic identity. Oxford and New York: Oxford University Press, 353-368.

Odden, David. 1985. An accentual approach to tone in Kimatuumbe. In: Didier L. Goyvaerts. (ed.). African Linguistics. Amsterdam-Philadelphia: John Benjamins, 345-419.

Odden, David. 1995. Tone: African languages. In: John A. Goldsmith. (ed.). The handbook of phonological theory. Cambridge, MA - Oxford, UK: Blackwell, 444-475.

Oliver, Roland. 1966. The problem of the Bantu expansion. Journal of African History 7:371376.

Paulme, Denise. 1954. Les gens du riz : Kissi de Haute-Guinée française. Paris : Librairie Plon.

Person, Yves. 1966. Des kru en Haute-Volta. Bulletin de l'Institut Français d'Afrique Noire série B : 485-491.

Pichl, Walter J. 1966. The Cangin group: A language group in northern Senegal. Pittsburgh, PA: Institute of African Affairs, Duquesne University.

Rodney, Walter. 1967. A reconsideration of the Mane invasions of Sierra Leone. Journal of African History 8:219-246.

Ross, Malcolm. 2007. Calquing and metatypy. Journal of Language Contact THEMA 1:116143.

Schaeffner, André. 1951. Les Kissi : une société noire et ses instruments de musique. Paris : Hermann et Cie.

Schuh, Russell G. n.d. The linguistic influence of Kanuri on Bade and Ngizim. Unpublished.

Segerer, Guillaume. 2000. L'origine des Bijogo : hypothèses de linguiste. In : Gérald Gaillard. (éd.). Migrations anciennes et peuplement actuel des basses côtes guinéennes : Actes du colloque international de l'Université de Lille 1. Paris: L'Harmattan.

Segerer, Guillaume. 2004. Sénégal, Gambie, Guinée-Bissau, Guinée, Sierra Leone, Liberia, A map showing the languages of Senegal, Gambia, Guinea-Bissau, Sierra Leone, and Liberia. Paris: Centre National de la Recherche Scientifique (CNRS).

Shack, William, and Skinner, Elliott. 1979. Strangers in African societies. Berkeley: University of California Press.

Sommer, Gabriele. 1992. A survey of language death in Africa. In: Matthias Brenzinger. (ed.). Language death and theoretical explorations with special reference to East Africa. Berlin: Mouton de Gruyter, 301-417. 
Thomas, Northcote W. 1919, 1920. Who were the Manes? Journal of the African Society 1920:176-188; 133-142.

Turay, Abdul Karim. 1971. Loanwords in Temne, a study of the sources and processes of lexical borrowing in a Sierra Leone language. $\mathrm{PhD}$ thesis, University of London, London.

Voeltz, F. K. Erhard. 1996. Les langues de la Guinée (Cahiers d'Étude des Langues Guinéennes 1) vol. 1. Conakry: Université de Conakry, Faculté des Lettres et Sciences Humaines.

Vydrine, Valentin. 1999. Manding-English Dictionary (Maninka, Bamana), vol. 1: A, B, D$D A D$. St. Petersburg: Dimitry Bulanin Publishing House.

Westermann, Diedrich. 1911. Die Sudansprachen: eine sprachvergleichende Studie. Hamburg: L. Friederichsen and Co.

Williams, Gordon. 1994. Intelligibility and language boundaries among the Cangin peoples of Senegal. Journal of West African Languages 24-1:47-67.

Wilmsen, Edward N. 1981. Land filled with flies. Chicago: University of Chicago Press.

Wilson, William André Auquier. 1989. Atlantic. In: John Bendor-Samuel. (ed.). The NigerCongo Languages. Lanham, MD - London, UK: University Press of America, Inc., 81-104.

Woodbury, Anthony C. 2003. Defining documentary linguistics. Language Documentation and Description 1:35-51. 